one a block away, mimicking other birds.

Checking later the same day, I heard the bird sing its own melodies with up to five repetitions, and imitations of more species than had been previously heard. Around 1700 my wife and I and Mrs. Iris McMurchy checked the area again, and heard and saw one bird, its imitations including yet other species of birds. Next day, about 0800 , Mrs. W. A. Elliott heard mimicking and saw two birds of the same general colour and slenderness on a TV antenna. They were close together, she said. Since then, no one has seen or heard anything here of the visitors.

Reports of at least four persons show that the mockingbird mimicked the song or call of the following animals: Yellow-shafted Flicker, Eastern Kingbird, Baltimore Oriole, Red-winged Blackbird, American Robin, House Wren, Black-billed Magpie, Blue Jay, Common Nighthawk, Black-capped Chickadee, Western Meadowlark, House Sparrow, Purple Martin, American Goldfinch, frog and dog.

\section{PURPLE MARTINS NEAR WHYTEWOLD, MANITOBA}

JEAN BANCROFT, 306 - 200 Tuxedo Avenue, Winnipeg, Manitoba, R3P OR3.

During the past few years I have been able to observe several colonies of these delightful members of the swallow family in and around Whytewold, in the southwest corner of Lake Winnipeg.

I was delighted, therefore, in the spring of 1979 , to notice two new colony houses had been erected, enabling me to keep a record of 12 colonies (two of which were not in compartment houses).

The prevalence of martins in this area could be due to the fact that there is always an abundance of insects, particularly mosquitoes, fishflies and dragonflies. To my knowledge, during the past 25 years, there has never been any spraying for mosquito abatement.

In general, the colony houses contained from 12 to 18 compartments and stood on poles ranging from approximately $3 \mathrm{~m}$ to $7 \mathrm{~m}$ high. However, this summer I discovered a unique colony house, situated in a beautiful garden just off a main highway near Gimli (which is approx. $24 \mathrm{~km}$ north of Whytewold). This colony house contained $56 \mathrm{com}$ partments and stood on a pole a little less than $3 \mathrm{~m}$ in height. As I thought it was very interesting I approached the owner of the property and she told me her husband had built it 15 years ago, erecting the circular bottom part one year and adding the top part the following year. Every year the colony house apparently has been full. Each compartment comes apart and is cleaned out every fall. When the house was first erected there was a very large open lawn area but, even though there are many small trees in the garden now, the birds' flight to the house is not obstructed in any way.

Martins, as Godfrey states in his Birds of Canada prefer "open places ... forage both high and low over open water, marshes, and open terrain." Open terrain seems to be very important. For instance, for four years I have observed another colony house of 14 compartments, close to a busy roadway but the number of occupants decreased this summer, presumably due to poor accessibility to the entrances. The house was 
erected on top of a sawed-off maple about $4 \mathrm{~m}$ high, and new sprouts had grown too lengthy. Eventually, the owner cut off some of the leafy branches and thus several pairs were able to complete the nesting period.

Two colonies were of particular interest, in that they were not in compartment houses. One which I have observed for several years was under the gable where two buildings were joined together. My binoculars revealed that several females were sitting in total darkness on nests which appeared to be small heaps of grasses. The second colony was at the other side of the same building, close to the roof. I discovered that martins were flying in with food underneath one of the aluminum ventilator flaps of an air-conditioning unit. I could see some bits of grass and a white feather protruding. Later on in the season I observed fledglings on the roof above the nesting area.

It is claimed by some people that martins abandon a colony house if sparrows nest in any compartment. However, from my observations, I know that this is not always the case. In one yard there were two 12compartment houses where five sparrow families were living peaceably all season. In four other successful colony houses I noticed one or two pairs of sparrows nesting.

In observing the colonies several incidents in particular interested me. Amongst these were the following:

A. I could hardly believe my eyes when I noticed, on two occasions during nest building, a male flying onto a stoop with two horizontal twigs in his beak, one being at least $1.3 \mathrm{~cm}$ longer than the diameter of the hole. He flew three times at the hole and then with a quick determined lunge he disappeared into the hole with the sticks.
B. No matter how many compartments were in a colony house both male and female knew the entrance to their own compartment. How they have this sense of recognition is another of Nature's mysteries.

C. I was astonished when I noticed two adults fly to the holes with a large dragonfly in their beaks and, in each case, a young martin gulped it down in one piece.

I find Godfrey's remarks in regard to these members of the swallow family very appealing when he says, "their graceful flight, pleasant voices, gentle ways, and economically beneficial food habits make them a real asset to have about."

\section{PRAIRIE NEST RECORD SCHEME REQUIRES NEW PARTICIPANTS}

The number of persons taking part in the Prairie Nest Record Card Scheme has been dropping and very few new contributors are replacing them. Some of the contributors have moved to other areas of Canada and likely others have lost interest or are no longer able to take an active part. More contributors are needed for all three provinces, but particularly Alberta and Saskatchewan.

Prairie Nest Record Cards are used by government departments, graduate students and other persons doing research on birdlife. Therefore it is a valuable program to continue.

Information and blank cards can be obtained from H. W. R. Copland, Prairie Nest Records Card Scheme, Manitoba Museum of Man and Nature, 190 Rupert Avenue, Winnipeg, Manitoba, R3B ON2. 